\title{
Loss of seed viability in onion (Allium cepa L.) in relation to degradation of lipids during storage
}

\author{
Vishwanath Rohidas Yalamalle* \\ ICAR-Directorate of Onion and Garlic Research, Pune-412105 (Maharashtra), India \\ Nilesh Nivrutti Gaikwad \\ ICAR-National Research Center on Pomegranate, Solapur- 413255 (Maharashtra), India \\ Dinesh Manohar Ithape \\ ICAR-Directorate of Onion and Garlic Research, Pune-412105 (Maharashtra), India \\ Ashok Kumar \\ ICAR-Directorate of Onion and Garlic Research, Pune-412105 (Maharashtra), India \\ Kalyani Gorrepati \\ ICAR-Directorate of Onion and Garlic Research, Pune-412105 (Maharashtra), India \\ Major Singh \\ ICAR-Directorate of Onion and Garlic Research, Pune-412105 (Maharashtra), India \\ ${ }^{*}$ Corresponding author. E-mail: vishwanath_yal@yahoo.com
}

\section{How to Cite}

Yalamalle V. R. et al. (2020). Loss of seed viability in onion (Allium cepa L.) in relation to degradation of lipids during storage. Journal of Applied and Natural Science, 12(4): 635 - 640. https://doi.org/10.31018/jans.v12i4.2431

\begin{abstract}
Onion seeds have one of the lowest longevity among the cultivated crops as it loses viability within a year. The unmarketable seeds have no reported food value or feed value. Onion seeds contain considerable oil content which has potential industrial utility. The present study reports the changes in the quality of seed oil extracted from seeds stored for one year (2019-2020), after which the seeds were unmarketable due to low germination. The physico-chemical properties of seed oil were studied in four onion (Allium cepa L.) varieties (Bhima Safed, Bhima Super, Bhima Dark Red and Bhima Shakti) by standard analytical test. The per cent oil content varied from $12.94 \%-16.02 \%$ and storage resulted in $0.64 \%$ loss in seed oil content. The mean seed germination in freshly harvested seeds was $80.50 \%$, which declined to $52.33 \%$ after one year of ambient storage. The electrical conductivity, which measures the membrane integrity increased by $108.60 \%$ in one-year-old seeds. The physicochemical properties of the seed oil deteriorated with the age of the seed. In comparison to the control, the acid values and peroxide values of the seed oil increased by $51.11 \%$ and $12.90 \%$ respectively, while saponification value decreased by $36.18 \%$. Among the varieties, Bhima Dark Red had the highest degradation in the seed storability and vigour, which also had the highest deterioration in the lipid quality. The present study reports for the first time the degradation of seed lipids during ageing in onion which might be contributing to the poor storability of onion seeds.
\end{abstract}

Keywords: Acid value, Onion seed oil, Peroxidase value, Saponification value, Seed viability

\section{INTRODUCTION}

Onion (Allium cepa L.) is an important vegetable crop grown in almost all parts of the world as a flavouring agent in food preparation. The medical value of onion is well-documented, its regular consumption reduces the risk of cardiovascular diseases (Challier, et al., 1998) and it has anti-inflammatory (Wilson and Demmig $\square$ Adams 2007) anti-diabetic (Wu and $\mathrm{Xu}$ 2014), anti-microbial (Sobolewska et al., 2016) and hypolipidemic properties (Galavi and Hosseinzadeh, 2020). The onion seeds are also consumed in some of the worlds. The medicinal values of the onion seed oil are also documented. Onion seeds contain $20.4 \%$ lipids, $24.8 \%$ protein, cysteine derivatives, minerals etc. (Dini et al., 2008). The onion seed oil contains a high proportion of polyunsaturated fatty acid content with linoleic acid being a major constituent $(64 \%-65 \%)$. It contains high levels of $\alpha$-tocopherol (634 mg/L). The onion seed oil is reported to have anti-inflammatory, antioxidant and antimicrobial properties (Sim and Nyam, 2020). The quality of the seed oil extracted depends on the storages conditions and the storage period (Michael, 1998).

Seed ageing is related to the loses of the ability to scavenge the reactive oxygen species (ROS) and peroxides (Sau et al., 2019; Yalamalle et al., 2019) The seed deterioration process also induce qualitative and quantitative changes in nucleic acids, protein and li- 
pids (Kurek et al., 2019). The ROS produced during ageing leads to peroxidation of the lipids in the membrane. The damages to the cellular membrane lead to loss of membrane integrity and solute leakage. Changes in the lipid quality parameters like acid value, peroxide value and saponification value can provide insight into seed ageing process (lqbal et al., 2002).

Onion seeds have one of the lowest viabilities among cultivated crops. It loses the seed viability withing a year (Yalamalle and Tomar, 2019). Poor germination is not just an issue in stored seeds, but many times freshly harvested seeds are unmarketable due to poor germination (Tajbakhsh et al., 2004). Seed legislation bars the sale of seeds having germination below the minimum prescribed standards, in India, it is $70 \%$. Such seeds are either discarded or admixture with seed lots with higher germination, causing disposal concerns or losses to the seed purchasers/ farmers (Gupta and Sharma, 2014).

Onion seeds are rich in lipids, and generally, seeds with high lipids content are poor storer (Yadav et al., 2013). Apart from use for propagation, there is a limited commercial utility of onion seeds, but have potential industrial uses like biodiesel, industrial lubricants, drying oils, cosmetics etc. Thus there is a need to find the changes in the changes in seed oil quality extracted from seeds after storage. The sale of oils and fats for consumption is governed by quality standards set by international agencies like Codex Standard for Named Vegetable Oils (Codex-standard, 1999) or local agencies like- FSSAI for India (FSSAI, 2015). The oil for consumption has to meet the standards set, if not such oils can be utilized for industrial uses. Some of the quality standards include- peroxidation value is an important method to estimate the oil quality; it indicates the extent of primary oxidation already occurred in the lipid. It is the most important quality parameter tested during production, storage and marketing of oils and fats. The acid value determines the free fatty acid present in the oil. Like peroxidase value, it also measures the relative rancidity as free fatty acid are produced during decomposition of triglycerides. Saponification value represents all the free fatty acid present in an oil (free and esterified). Lipids with high saponification value produce more glycerin and less biodiesel. Oils extracted from coconut, palm kernels, babassu etc. have high saponification value, and they also produce higher foam and are suitable for the soap industry. Physico-chemical characteristics values signify the quality of the oil and hence the economic value of the seed oil.

To best of our knowledge, there are no reports on the changes in the physico-chemical properties of onion seed oil and the quality changes with loss of seed viability. Particularly the changes in seed oil quality of seed lots stored beyond one year, when the seed lots have lost have viability or seeds which are unmarketable under Indian minimum seed certification standards,
(2013). The main objective of the present study was to study the changes in seed lipids during storage and to investigate the reasons for poor storability of onion seeds.

\section{MATERIALS AND METHODS}

Plant material: Seeds of onion (Allium cepa L.) varieties, Bhima Safed, Bhima Super, Bhima Dark Red and Bhima Shakti, was procured from the Seed Unit, ICAR -Directorate of Onion and Garlic Research, Pune, India. The seeds (approximately $1000 \mathrm{~g}$ per pack) were hermetically sealed and stored for 12 months at room temperature $\left(12.20^{\circ} \mathrm{C}-38.55^{\circ} \mathrm{C}\right)$. The seeds oil quality was estimated thrice, first one was on freshly harvested seed, the second was after 6 months of storage and third was after 12 months of storage.

Estimation of physico-chemical properties of seed oil: The seed oil was extracted mechanically by using a hydraulic press (Hanora A type, National Engineering, 541 DukEun Dong, Duk Yang Gu, Goyang City, Gyeonggi-Do, South Korea). Clean and dry seeds of each variety (approximately $1 \mathrm{Kg}$ was fed into a hydraulic press, which was operated at $80{ }^{\circ} \mathrm{C}$ and 500 $\mathrm{kg} / \mathrm{cm}^{2}$ pressure. The seed oil was vacuum filtered and centrifuged at $8000 \mathrm{rpm}$ for 10 minutes remove any debris. The samples were preserved in ambercoloured bottles, the headspace was purged with liquid nitrogen and stored at $4{ }^{\circ} \mathrm{C}$ until analysis. The per cent seed oil content in seeds was determined by Soxhlet method, using petroleum ether as solvent at $50{ }^{\circ} \mathrm{C}$. The physico-chemical analysis of the lipids i.e peroxide value- which measures the extent of primary oxidation in the lipid, acid value- which measures free fatty acid present in the oil and saponification value which measures the average chain length of fatty acid was done as per Association of Official Analytical Chemists (AOCS 1990) (i) Peroxide value (method Cd 8-53) (ii) Acid value (method $\mathrm{Ca} 3 a-63$ ) (iii) and Saponification value (method $\mathrm{Cd} 3-25)$.

Electrical conductivity: In a $50 \mathrm{ml}$ beaker, $100 \mathrm{mg}$ seeds were weighed-in three replicates and to it, 25 $\mathrm{mL}$ distilled water was added. Then the beaker was placed at $20 \pm 1^{\circ} \mathrm{C}$ for 24 hours, the leachate was collected and the electrical conductivity (EC) was recorded with the help of a digital conductivity meter along with distilled water as control (Dadlani and Agrawal 1987).

Seed germination and seed vigour: In $150 \mathrm{~mm}$ diameter Petri plates, three replicates of 50 seeds were placed on $150 \mathrm{~mm}$-diameter moistened filter paper discs (Axiva, India catalogue No. 100150R). The Petri plates were placed in a BOD incubator set at 20 $\pm 1^{\circ} \mathrm{C}$ for 12 days (ISTA, 2015). The seedling dry weight and the seedling length were recorded on the $12^{\text {th }}$ day on 10 randomly selected seedlings. The seed vigour indices were calculated according to Abdul $\square$ Baki and Anderson (1973): vigour index-I (VI-I) = germination $\% X$ average length of 10 seedlings in $\mathrm{cm}$. 


\section{RESULTS AND DISCUSSION}

Seed oil content: The average oil content in freshly harvested seeds was $14.39 \%$, which was also statistically similar to the seeds stored at 6 months (Table 1). At the end of 12 -month storage, there was $0.64 \%$ reduction in the oil content. Among the varieties highest oil content was recorded in variety Bhima Shakti $(16.65 \%)$ and lowest in Bhima Super (12.51\%). The results are in agreement with Amalfitano et al., (2020), wherein the average onion oil in Italian variety Ramata di Montoro ranged from $14.9 \%-16.5 \%$. The reduction in seed oil content during storage has been previously reported by Neme et al, (2020) in sesame, which may be attributed to enzymatic breakdown of lipids for seed metabolism during storage.

Germination and seed vigour: Storage duration had a significant effect on the germination. The average germination in freshly harvested seeds was $80.50 \%$. After 6 months of storage, all varieties except Bhima Super maintained germination above Indian minimum seed standards, (2013) of (70\% for germination) (Table 2). At the end of 12-month storge, the average germination was $52.33 \%$ and none of the varieties maintained germination above the statutory requirement of $70 \%$. Among the varieties highest reduction in germination was recorded in Bhima Dark Red variety. The storage potential of different varieties differed which might be due to different maternal environments during seed development and/or varietal differences (Thirusendura et al., 2018, Yalamalle et al., 2020).

As expected the vigour of onion seeds decreased with the seed age. The average seedling length in freshly harvest seeds was $10.62 \mathrm{~cm}$. There was $69.64 \%$ and $115.41 \%$ reduction in seedling length in 6 months and 12-month-old seedlings respectively. By the end of 6 months nearly $100 \%$ reduction in the vigour was recorded and by the end of one year there was $218.75 \%$ reduction. The electrical conductivity measures the membrane integrity of the seeds. Seed ageing leads to accumulation of ROS, which damages the cellular membrane. The degraded membranes leach the solutes leading to loss of seed viability and vigour (Kurek et al., 2019; Yalamalle et al., 2020). In the present study, there was an increase in the EC with the seed age. In comparison to the freshly harvested seeds, there was $40.83 \%$ and $108.60 \%$ higher EC in 6 months and 12 months stored seeds, respectively (Table 3). Among the varieties highest mean EC was recorded in variety Bhima Dark Red, signifying higher deterioration. The highest degradation in seed quality parameters was also recorded in Bhima Dark Red variety. The rapid reduction in seed quality in onion,reported previously (Mollah et al., 2016, Yalamalle and Kuchlan 2016) were in there was up to $40-60 \%$ loss in seed viability within a short period under ambient conditions.

Changes in seed oil quality: Peroxide value signifies the extent of auto-oxidation of oils and fats. The peroxide value increased with the seed storage period and the highest value $(1.36 \mathrm{meq} / \mathrm{Kg})$ was recorded in 12 months stored seeds. After 12 months of storage among varieties, the highest peroxide value was recorded in Bhima Dark Red which also had the lowest seed quality after storage. The results are in agreement with previous studies by (lqbal et al., 2002) in cotton seeds and Suresh et al., (2018) in Jatropha curcas $L$ were in seed ageing increased the peroxidation value.

The acid value is the amount of the $\mathrm{KOH}$ required to neutralize the free fatty acids present in the oils. Like peroxidase value, it also measures the relative rancidity as free fatty acid are produced during decomposition of triglycerides. Even though there was a considerable reduction in the seed vigour after six months of storage the acid value did not differ significantly and the highest value was recorded after 12 months of storage $\left(0.70 \mathrm{mg} \mathrm{KOH} \mathrm{g}^{-1}\right)$ (Table 5). Among the varieties, the lowest mean acid value was recorded in Bhima Super and Bhima Safed, which also had a lower reduction in the seed quality during storage. Previous studies by de Oliveira et al. (2016) in Babassu palm seeds and Abduh et al. (2019) in Reutealis trisperma seeds also report an increase in the acid value with the seed age.

Table 1. Change in per cent oil content in onion varieties stored for different durations.

\begin{tabular}{|c|c|c|c|c|}
\hline \multirow[t]{2}{*}{ Variety (V) } & \multicolumn{3}{|c|}{$\begin{array}{l}\text { Per cent oil content } \\
\text { Storaqe period (D) }\end{array}$} & \multirow[t]{2}{*}{ Mean } \\
\hline & Initial & $6 \mathrm{~m}$ & $12 \mathrm{~m}$ & \\
\hline BDR & 14.36 & 16.10 & 13.45 & $14.66^{b}$ \\
\hline BST & 16.02 & 17.85 & 16.09 & $16.65^{\mathrm{a}}$ \\
\hline BSR & 12.94 & 12.34 & 12.25 & $12.51^{\mathrm{d}}$ \\
\hline BSD & 14.25 & 13.16 & 13.22 & $13.54^{c}$ \\
\hline Mean & $14.39^{\mathrm{a}^{\wedge}}$ & $14.85^{a}$ & $13.75^{b}$ & \\
\hline Interaction & S.Em \pm & LSD at & & \\
\hline $\mathrm{D}$ & 0.86 & $0.44^{* *}$ & & \\
\hline V & 0.99 & $0.51^{* *}$ & & \\
\hline $\mathrm{D} \times \mathrm{V}$ & 1.72 & $0.88^{* *}$ & & \\
\hline
\end{tabular}

** Significant at $P \leq 0.01$; BDR - Bhima Dark Red, BST-Bhima Shakti, BSR-Bhima Super, BSD- Bhima Safed. ^ values with same letters in a column/ row are not statistically significant. $m$ - months. The values represent the means of three samples $(n=3)$. 


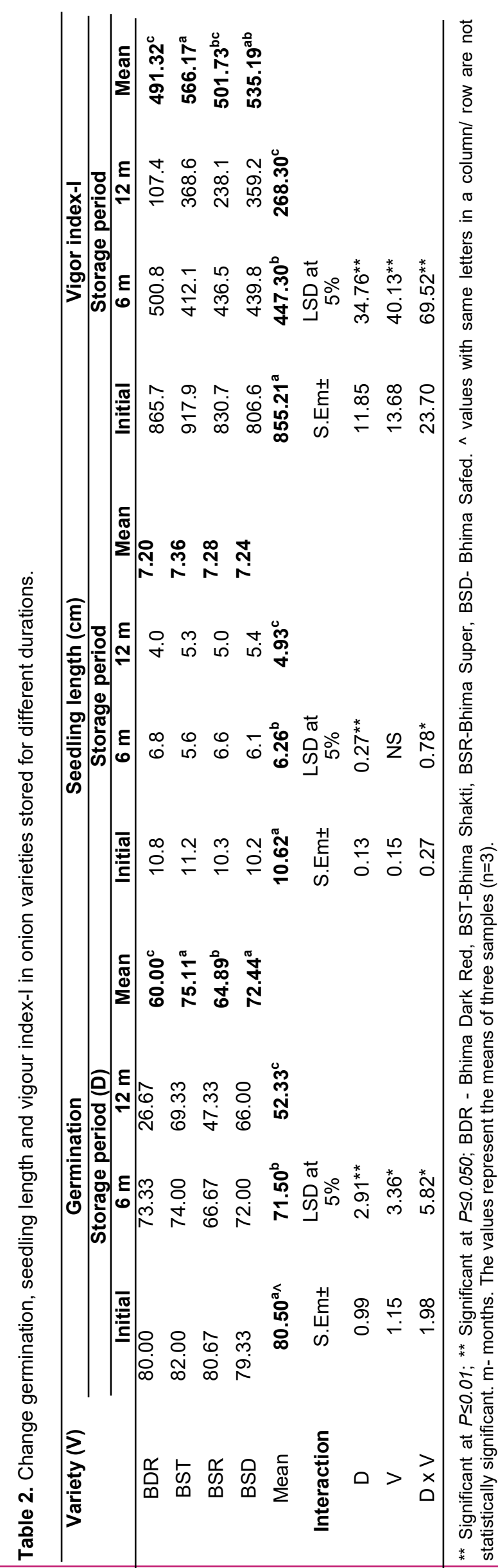

Saponification number represents all the free fatty acid present in an oil (free and esterified). The saponification value decreased with storage duration (Table 6). Among the varieties, highest mean saponification value during the storage was recorded in Bhima Dark Red (143.57 mg KOH gram ${ }^{-1}$ ). The reduction is saponification value during accelerated ageing has also been reported by lqbal et al., (2002) in cotton seeds which may be due to the reduction of average molecular weight of fatty acid due to bond breakage during seed ageing. The saponification value has industrial significance and oils with higher saponification value are best suitable for biodiesel.

The ROS accumulated during seed ageing, combine with oxygen to produce hydroperoxides. These hydroperoxides attack the lipids present in the seeds leading to lipid peroxidation. The stability of lipids in the seed is very crucial for the survival of the seeds since unsaturated fatty acids form a major component of the cell membranes and its degradation leads to loss of vigour and viability in onion seeds. The increase in the peroxide value and acid value in the onion seed with the seed ageing signifies that the seed ageing in onion is related to the breakdown of the fatty acids. Among the varieties, highest degradation of seed quality as well lipids was in seeds of Bhima Dark Red which indicates that Bhima Dark Red variety is a poor storer variety.

\section{Conclusion}

The present study concluded that the poor storability of onion (Allium cepa L.) seed shown to be related to the loss of membrane integrity and degradation of the fatty acids. Although the increased peroxide value $(1.36 \mathrm{meq} / \mathrm{Kg})$ and acid value $\left(0.70 \mathrm{mg} \mathrm{KOH} \mathrm{g}^{-1}\right)$ in stored seeds indicate the degradation of fatty acid attributing to the poor storability of the onion seeds, but the quality of the seed oil was within the maximum permissible limits of CODEX, (1999) standards for edible oil i.e. peroxide value (15 meq/kg oil) and acid value $(4.0 \mathrm{mg} \mathrm{KOH} / \mathrm{g}$ Oil). The utility of oil extracted from non-viable seeds could be explored for food and industrial application.

\section{Conflict of interests}

The authors declare that they have no conflict of interests.

\section{REFERENCES}

1. Abduh, M.Y., Syaripudin., Putril, L.W., Manurung, R. (2019). Effect of storage time on the moisture content of Reutealis trisperma seed and its effect on the acid value of the isolated oil and produced biodiesel. Energy Reports, 5:1375-1380. https://doi.org/10.1016/j.egyr.2019.0 9.066

2. Abdul Baki, A.A. and Anderson, J.D. (1973). Vigor determination in soybean seed by multiple criteria. Crop Science, 13(6): 630-33. https://doi.org/10.2135/ cropsci1973.0011183X001300060013x

3. Amalfitano, C., Golubkina, N.A., Del Vacchio, L., Russo, 
Table 3. Changes in electrical conductivity of onion varieties stored for different durations.

\begin{tabular}{|c|c|c|c|c|}
\hline \multirow{3}{*}{ Variety (V) } & \multicolumn{3}{|c|}{ Electrical conductivity $\left(\mu \mathrm{S}^{-1} \mathrm{~cm} \mathrm{~g}^{-1}\right)$} & \multirow{3}{*}{ Mean } \\
\hline & \multirow{2}{*}{\multicolumn{3}{|c|}{ Storage period (D) }} & \\
\hline & & & & \\
\hline BDR & 95.15 & 128.40 & 190.68 & $138.08^{\mathrm{a}}$ \\
\hline BST & 76.83 & 111.34 & 185.88 & $124.68^{\mathrm{b}}$ \\
\hline BSR & 73.00 & 94.10 & 157.95 & $108.35^{c}$ \\
\hline BSD & 79.65 & 123.36 & 142.70 & $115.24^{b}$ \\
\hline Mean & $81.16^{\mathrm{c}^{\wedge}}$ & $114.30^{b}$ & $169.30^{\mathrm{a}}$ & \\
\hline Interaction & S.Em \pm & LSD at $5 \%$ & & \\
\hline D & 3.59 & $9.11^{* *}$ & & \\
\hline V & 3.11 & $10.52^{* *}$ & & \\
\hline $\mathrm{D} \times \mathrm{V}$ & 6.22 & $18.23^{* *}$ & & \\
\hline
\end{tabular}

** Significant at $P \leq 0.01$; BDR - Bhima Dark Red, BST-Bhima Shakti, BSR-Bhima Super, BSD- Bhima Safed. ^ values with same letters in a column/ row are not statistically significant. $m$ - months. The values represent the means of three samples $(n=3)$.

Table 4. Changes in Peroxide value of seed oil extracted from onion varieties stored for different durations.

\begin{tabular}{|c|c|c|c|c|}
\hline \multirow{3}{*}{ Variety (V) } & \multicolumn{3}{|c|}{ Peroxide value (meq/Kg) } & \multirow{3}{*}{ Mean } \\
\hline & \multicolumn{3}{|c|}{ Storage period (D) } & \\
\hline & Initial & $6 \mathrm{~m}$ & $12 \mathrm{~m}$ & \\
\hline BDR & 1.22 & 0.98 & 1.38 & $1.18^{\mathrm{a}}$ \\
\hline BST & 0.72 & 0.72 & 1.33 & $0.94^{b}$ \\
\hline BSR & 0.83 & 1.12 & 1.36 & $1.10^{\mathrm{a}}$ \\
\hline BSD & 0.82 & 1.27 & 1.36 & $1.15^{\mathrm{a}}$ \\
\hline Mean & $0.90^{\mathrm{c}}$ & $1.02^{b}$ & $1.36^{\mathrm{a}}$ & \\
\hline Interaction & S.Em \pm & LSD a & & \\
\hline D & 0.03 & $0.07^{*}$ & & \\
\hline V & 0.03 & $0.09^{*}$ & & \\
\hline $\mathrm{D} \times \mathrm{V}$ & 0.05 & $0.15^{*}$ & & \\
\hline
\end{tabular}

*Significant at $P \leq 0.05$; BDR - Bhima Dark Red, BST-Bhima Shakti, BSR-Bhima Super, BSD- Bhima Safed. ^ values with same letters in a column/ row are not statistically significant. $m$ - months. The values represent the means of three samples $(n=3)$.

Table 5. Changes in the Acid value of seed oil extracted from onion varieties stored for different durations.

\begin{tabular}{|c|c|c|c|c|}
\hline \multirow{3}{*}{ Variety (V) } & \multirow{2}{*}{\multicolumn{3}{|c|}{$\begin{array}{c}\text { Acid value ( } \mathrm{mg} \mathrm{KOH} \mathrm{g}^{-1} \text { of oil) } \\
\text { Storage period (D) }\end{array}$}} & \multirow{3}{*}{ Mean } \\
\hline & & & Storage period (D) & \\
\hline & Initial & $6 \mathrm{~m}$ & $12 \mathrm{~m}$ & \\
\hline BDR & 0.57 & 0.64 & 0.75 & $0.65^{\mathrm{ab}}$ \\
\hline BST & 0.63 & 0.56 & 0.62 & $0.60^{c}$ \\
\hline BSR & 0.70 & 0.62 & 0.80 & $0.71^{\mathrm{a}}$ \\
\hline BSD & 0.60 & 0.60 & 0.62 & $0.60^{c}$ \\
\hline Mean & $0.62^{\mathrm{a}^{\wedge}}$ & $0.60^{\mathrm{a}}$ & $0.70^{b}$ & \\
\hline Interaction & S.Em \pm & LSD a & & \\
\hline $\mathrm{D}$ & 0.02 & $0.05^{* *}$ & & \\
\hline V & 0.02 & $0.06^{* *}$ & & \\
\hline $\mathrm{D} \times \mathrm{V}$ & 0.03 & $0.10^{*}$ & & \\
\hline
\end{tabular}

** Significant at $P \leq 0.01$; *Significant at $P \leq 0.05$; BDR - Bhima Dark Red, BST-Bhima Shakti, BSR-Bhima Super, BSD- Bhima Safed. ^ values with same letters in a column/ row are not statistically significant. $m$ - months. The values represent the means of three samples ( $n=3$ ).

Table 6. Changes in Saponification value of seed oil extracted from onion varieties stored for different durations.

\begin{tabular}{|c|c|c|c|c|}
\hline \multirow{3}{*}{ Variety (V) } & \multicolumn{3}{|c|}{ Saponification value ( $\mathrm{mg} \mathrm{KOH} \mathrm{g}^{-1}$ of oil) } & \multirow{3}{*}{ Mean } \\
\hline & \multicolumn{3}{|c|}{ Storage period (D) } & \\
\hline & Initial & $6 \mathrm{~m}$ & $12 \mathrm{~m}$ & \\
\hline BDR & 173.91 & 132.66 & 124.13 & $143.57^{\mathrm{a}^{\wedge}}$ \\
\hline BST & 176.25 & 116.18 & 104.48 & $132.30^{b}$ \\
\hline BSR & 163.62 & 121.13 & 99.02 & $127.93^{\text {bc }}$ \\
\hline BSD & 158.95 & 117.36 & 101.68 & $126.00^{c}$ \\
\hline Mean & $168.18^{a}$ & $121.83^{b}$ & $107.33^{c}$ & \\
\hline Interaction & S.Em \pm & LSD at $5 \%$ & & \\
\hline $\mathrm{D}$ & 1.61 & $4.73^{* *}$ & & \\
\hline $\mathrm{V}$ & 1.86 & $5.47^{* *}$ & & \\
\hline$D \times V$ & 3.23 & $9.47^{* *}$ & & \\
\hline
\end{tabular}

** Significant at $P \leq 0.01$; BDR - Bhima Dark Red, BST-Bhima Shakti, BSR-Bhima Super, BSD- Bhima Safed. ^ values with same letters in a column/ row are not statistically significant. $m$ - months. The values represent the means of three samples $(n=3)$. 
G., Cannoniero, M., Somma, S., Morano, G., Cuciniello, A., Caruso, G. (2020). Yield, antioxidant components, oil content, and composition of onion seeds are influenced by planting time and density. Plants, 8: 293. https:// doi.org/10.3390/plants8080293

4. AOCS. (1990). Official Methods and Recommended Practices of the American Oil Chemists Society. 4th ed. Champaign, III, USA.

5. Challier, B., Perarnau, J.M. and Viel, J.F. (1998). Garlic, onion and cereal fibre as protective factors for breast cancer: A French case-control study. European Journal of Epidemiology, 14(8): 737-47. https://doi.org/10.1023/ A: 1007512825851

6. CODEX. (1999). Codex standard for named vegetable oils (Codex-Stan 210 - 1999). Retrieved November, 1 2020 from http://www.fao.org/input/download/standard s/336/CXS_210e_2015.pdf

7. Dadlani, M. and P K Agrawal. (1987). Techniques in Seed Science and Technology. South Asian Publishers, New Delhi.

8. Dini, I., Tenore, G.C. and Dini, A. 2008. Chemical composition, nutritional value and antioxidant properties of Allium caepa L. Var. Tropeana (red onion) seeds. Food Chemistry 107(2): 613-21. https://doi.org/10.1016/ j.foodchem.2007.08.053

9. FSSAI . (2015). Manual for Analysis of Oils and Fats. Food safety and standards authority of India Ministry of Health and Family Welfare Government of India New Delhi.

10.Galavi, A., Hosseinzadeh, H. (2020). The effects of Allium cepa L.(onion) and its active constituents on metabolic syndrome: A review. Iranian Journal of Basic Medical Sciences, 23: 1-14. https://dx.doi.org/10.22038//JBMS.20 20.46956 .10843

11.Gupta, R.P. and Sharma, H.P. (2014). Onion seed production- scope, challanges and future strategy to meet the demand of quality seed. In Brain Storming Session on Crop Improvement and Seed Production of Onion, Nashik, India: National Horticultural Research and Development Foundation, 1-12.

12.lqbal, N., Basra, M.A.S. and Khalil, Rehman-ur. (2002). Evaluation of vigour and oil quality in cottonseed during accelerated ageing. International Journal of Agriculture and Biology, 4(3): 318-22.

13.Indian minimum seed certification stanadards. (2013). The Central Seed Certification Board

14.Department of Agriculture and Co-operation Ministry of Agriculture Government of India New Delhi, pp 337-339.

15.ISTA. (2015). ISTA Rules Full Issue. International Rules for Seed Testing, 2015(1): 1-276.

16.Kurek, K., Plitta-Michalak, B., Ratajczak, E. (2019). Reactive oxygen species as potential drivers of the seed aging process. Plants, 8: 174. https://doi.org/10.3390/ plants8060 174

17.Michael, Bockisch. (1998). Vegetable fats and oils. In Fats and Oils Handbook, ed. Bockisch Michael. AOCS press, Urbana Illinios, 174-344. https:// linkinghub.elsevier.com/retrieve/pii/ B9780981893600500093.

18.Mollah, M.R.A., Ali, M.A., Prodhan, M.Z.H., Rahman, M.M. and Alam, M.J. (2016). Effect of containers on storability of true seeds of onion. European Journal of Biomedical and Pharmaceutical Sciences, 3(1): 1-4.

19.Neme, K., Tola, Y.B., Mohammed, A., Tadesse, E. and
Astatkie, T. (2020). Effects of variety, storage container, and duration on the physical properties, oil content, germination capacity, and seed loss due to Plodia interpunctella infestation of Ethiopian sesame. Journal of the Science of Food and Agriculture. https://doi.org/10.1002/jsfa.10691

20.de Oliveira, R.A.D., da Conceição Neves, S., Ribeiro, L.M., Nascimento Lopes, P.S., Silvério, F.O. (2016). Storage, oil quality and cryopreservation of babassu palm seeds. Industrial Crops and Products 91: 332-39. https:// doi.org/10.1016/j.indcrop.2016.07.039

21.Sau, S., Pal, B., Sarkar, S. and Sarkar, T. (2019). Influence of seed priming on germination and seedling vigour of wood apple (Feronia Limonia Swingle). International Journal of Bio-resource and Stress Management, 10(2): 128-36. https://doi.org/10.23910/IJBSM/2019.10.2.1967

22.Sim, Y.Y. and Nyam, L.K. (2020). Cold pressed onion (Allium Cepa L.) seed oil. In Cold Pressed Oils, Elsevier, 295-307. https://doi.org/10.1016/C2018-0-03151-5

23.Sobolewska, D., Michalska, K., Podolak, I. and Grabowska, K. (2016). Steroidal saponins from the genus Allium. Phytochemistry Reviews, 15(1): 1-35. https:/l doi.org/10.1007/s11101-014-9381-1

24.Tajbakhsh, M., Brown, P., Gracie, A., Spurr, C., Donovan, N., Clark, R.J. (2004). Mitigation of stunted root abnormality in onion (Allium cepa L.) using seed priming treatments. Seed Science and Technology, 32(3): 683-92. https://doi.org/10.15258/sst.2004.32.3.04

25.Thirusendura, S.D., Saraswathy, S. (2018). Seed viability, seed deterioration and seed quality improvements in stored onion seeds: a review. The Journal of Horticultural Science and Biotechnology, 93(1): 1-7. https:// doi.org/10.1080/14620316.2017.1343103

26.Wilson, E.A. and Demmig $\square$ Adams, B. (2007). Antioxidant, antiinflammatory, and antimicrobial properties of garlic and onions. Nutrition and Food Science, 37(3): 178-83. https://doi.org/10.1108/00346650710749071

27.Wu, H. and Xu, B. (2014). Inhibitory effects of onion against $\alpha$-glucosidase activity and its correlation with phenolic antioxidants. International Journal of Food Properties, 17(3): 599-609. https://doi.org/10.1080/10942 912.2012 .654562

28.Yadav, S.K., Yadava, D.K., Vasudev, S., Yadav, S., Kumar, P.R., Nigam, R . (2013). Assessment of seed quality and oil content in different branches of Indian mustard (Brassica juncea) cultivars at different storage intervals. Indian Journal of Agricultural Sciences, 83(2): 227-233.

29.Yalamalle, V.R. and Kuchlan, M.K. (2016). Safe storage of onion (Allium cepa $L$ ) seeds under moisture impervious packets with fungicide treatment. Environment and Ecology, 34(4D): 2453-57.

30.Yalamalle, V.R., Ithape, D.M., Kumar, A., Bhagat, K., Ghosh S. and Singh, M. (2020). Seed treatment with 5azacytidine reduces ageing-induced damage in onion seeds. Seed Science and Technology, 48 (3): 407-412. https://doi.org/10.15258/sst.2020.48.3.09

31.Yalamalle, V.R. and Tomar, B.S. (2019). Effect of scape regulation on seed yield and quality in onion (Allium cepa). Indian Journal of Agricultural Sciences, 89(1): 56-59.

32. Yalamalle, V.R., Tomar, B.S., Jain, S.K., Arora, A., Kumar, A. and Munshi, A.D. (2019). Spermine induced protection of onion seed vigour and viability during accelerated ageing. Journal of Environmental Biology, 40(5): 107983. http://doi.org/10.22438/jeb/40/5/MRN-1047 